\title{
Histological Damage at Gonad of Faunus ater (Gastropod Mollusk) Obtained from Heavy Metal Contaminated River
}

\author{
Rahmi Agustina ${ }^{1,2^{*}}$, M Ali Sarong ${ }^{3}$, Fredinan Yulianda ${ }^{4}$, \\ Suhendrayatna ${ }^{5}$, Ervina Dewi ${ }^{2}$ \\ 1 Graduate School of Mathematics and Applied Sciences, Universitas Syiah Kuala, Banda Aceh Indonesia \\ 2 Departement of Biology, Faculty of Teacher Training and Education, Jabal Ghafur University, Sigli \\ Indonesia 24171 \\ 3 Departement of Biology, Faculty of Teacher Training and Education, Universitas Syiah Kuala, Banda Aceh \\ Indonesia 23111 \\ ${ }^{4}$ Departement of Water Resources Management, Faculty of Fisheries and Marine Sciences, Bogor Agricultural \\ University, Bogor Indonesia 16680 \\ ${ }^{5}$ Department of Chemical Engineering, Faculty of Engineering, Universitas Syiah Kuala, Banda Aceh \\ Indonesia 23111 \\ * Corresponding author's e-mail: ami.binti.asyar@gmail.com
}

\begin{abstract}
The cause of the histological damage of Faunus ater (gastropod mollusk) gonad has been identified in the samples from two rivers, namely Bale River and Reuleng River which flow through residential, agricultural and industrial areas. The heavy metal concentration within the tissue of Faunus ater was analyzed with Atomic Absorption Spectrophotometer (Shimadzu AA 630). Meanwhile, the histological damage on gonads was observed microscopically. Afterwards, the damage levels obtained from the two respective rivers were compared and analyzed with $t$-test. The results confirm the histological damage that occurred in the gonads of Faunus ater collected from the two rivers. The gonadal damage of female Faunus ater from both rivers was found not to be significantly different, observed by the number of developed and damaged oocytes. It was also found that the gonads of male Faunus ater collected from Bale Riverl, have higher quantity of spermatogenic cells, in which they experience greater necrosis than the ones from Reuleng River.
\end{abstract}

Keywords: Bale River, Reuleng River, heavy metal, Faunus ater, gonad

\section{INTRODUCTION}

The Reuleng River and Bale River are located in Aceh Besar District, Aceh Province, Indonesia. In 2004, a great tsunami jeopardized these rivers. Lhoknga and Leupung are the two worst impacted areas of the tsunami. Reuleung is a major river that stretches from the east end of Leupung sub-district to Indian Ocean. The Reuleng river holds a significant role for the community it flows through. This river carries abundant natural resources such as sands, fishes, snails, etc. The watershed is close to the residential area where various domestic activities take place that in fact contribute to a significant impact as the contaminant sources.

Bale River is located in Lhoknga Sub-district, besides flowing through residential area, this river also flows through the cement factory area. The washing water used for the factory's machines, is discharged to this river. A number of aquatic biotas such as mollusk, including Faunus ater, are certainly affected by the occasionally greasy and blackened river.

The Reuleng River and Bale River watersheds are suspected to be contaminated due the domestic and industrial activities around; hence, monitoring and evaluation is required against 
the water condition as one of the preventive approaches. One of the most feared pollutants is heavy metal (Müller, 2017).

Heavy metals constitute one of the commonly found environmental pollutants in the waters. Heavy metals can also negatively affect the health of humans using the water as well as the aquatic organisms. The presence of heavy metals in organism tissue can be from natural or anthropogenic sources (Sharaf and Shehata, 2015). Intense industrial and anthropogenic activities caused an excessive release of heavy metal waste to the environment (Duruibe et al., 2007).

An organism can be exposed to heavy metals either directly from the environment or from other organism through food chain (Anna Jakimska et al., 2011). The heavy metals in the water can later form sediment, causing the high possibility of heavy metal exposure to the people who use the water. The heavy metal contaminated water can be toxic for living organisms (Govind and Madhuri, n.d.).

The pollution affects the physiochemistry of the water, sedimentation and biological components, especially the quality and the quantity of Faunus ater (Udayantha and Munasinghe, 2012). Founus ater is one of the healthy and cheap protein resources that contains greater amino acid cysteine amount than any other protein resources (Gatsogiannis et al., 2015). After the tsunami in 2004, the local consumption of Faunus ater was found to be increasing, especially in the rural villages. In several villages, which are located near either the Bale River such as Meunasah Bale and Meunasah Baro Village or the Reuleng river such as Layen Village and Mesjid Leupung Village, Faunus ater collected from the river is sold for consumption. Therefore, it is important to ensure the high quality of the consumed Faunus ater.

\section{METHODOLOGY}

A water sample was taken within three months interval from February to April 2017. The sample collection took place in Bale River, Lhoknga Subdistrict and Reuleng River, Leupung Sub-district, Aceh Besar District. The histological analysis of the Faunus ater reproduction system was conducted in the histology laboratory at the Faculty of Veterinary, Syiah Kuala University. The histological analysis included the following steps: the shell was removed, then the gonad organ was retrieved; next, the histological stock was prepared with the paraffin method. A gonad specimen was inserted to Bouin fixative solution; then, it was consecutively dehydrated with $70 \%, 80 \%, 90 \%$, $95 \%$ and $100 \%$ alcohol, cleared in xylol, infiltrated and embedded in paraffin block at $56-58^{\circ} \mathrm{C}$. The embedded stock was incised with 5 microns density using rotary microtome.

Each sampling was done with 4 incisions with 10 incisions interval and placed on the glass objects which were coated with an adhesive solution. In order to observe the ovotestis tissue, the stock was colored with Hematoxylin Eosin (HE) method which refers to Gridley (1960). The gonadal tissue observation was conducted with light microscope at $10 \times 40$ magnification. Each incision was observed for three fields of view; thus, there were 12 fields of view for each repetition.

The observed parameters in this study included the number of oocyte/mature sperm, oocyte/ immature sperm and oocyte/damaged sperm.

\section{STATISTICAL ANALYSIS}

The data obtained from the observation of the number of oocyte/mature sperm, oocyte/immature sperm and oocyte/damaged sperm, were analyzed using t-test (Sudjana 2005), with the equation below:

$$
t=\frac{\bar{X} 1-\bar{X} 2}{\sqrt{\frac{S_{1}^{2}}{n_{1}}+\frac{S_{2}^{2}}{n_{2}}}}
$$

where: $S$ : Standard deviation

$n 1$ : Group 1 quantity

n2: Group 2 quantity

$X 1$ : Group 1 average

$X 2$ : Group 2 average

\section{RESULT AND DISCUSSION}

\section{$\mathrm{Pb}$ and $\mathrm{Zn}$ content in Faunus ater}

Table 1 exhibits the contents of $\mathrm{Pb}$ and $\mathrm{Zn}$ which were detected in Faunus ater from the Bale River and Reuleng River. Statistically, there is no significant difference $(\mathrm{P}>0.05)$ observed from the comparison of the samples from the Reuleng River and Bale River, even though the Bale River 
was expected to exhibit higher $\mathrm{Pb}$ and $\mathrm{Zn}$ concentrations due to the near industrial activities. This insignificant difference of heavy metal contamination is probably caused by the similar pollution source. Through an observation in the Reuleng River, it was visually observable that there were many domestic wastes. Due to its location that close to agricultural and residential area, the wastes produced by the anthropogenic activities were directly released to the river. Generally, domestic waste contains solid (such as rinds, vegetables, plastics, cans, bottles, etc.) and liquid wastes. These facts contribute to the presence of $\mathrm{Pb}$ in the water. Meanwhile, in the upstream river that is surrounded by rock hill, the natural release of $\mathrm{Zn}$ can occur during the rain to the river body. Moreover, the anthropological activities such as sand mining and land excavation also contribute to the heavy metals release, thus eventually leading to the accumulation of $\mathrm{Zn}$. Besides, the presence of both $\mathrm{Pb}$ and $\mathrm{Zn}$ in Bale River is suggested to be coming from the machine washing process within the cement industry near the river. The threshold of $\mathrm{Pb}$ accumulation (according to Indonesian law) is $1.5 \mathrm{mg} / \mathrm{kg}$, where the concentration in Fausnus ater detected in this study far exceeded the threshold (Table 1)

The $\mathrm{Pb}$ and $\mathrm{Zn}$ metal pollution in waters is possibly visually unobservable even against the Faunus ater itself, in which diseases can be observed; however, the pollution may reduce the fecundity of Faunus ater population, which

Table 1. Concentrations of $\mathrm{Pb}$ and $\mathrm{Zn}$ in Faunus ater in the Bale River and Reuleung River

\begin{tabular}{|c|c|c|}
\hline Location & Concentration of $\mathrm{Pb}$ & Concentration of $\mathrm{Zn}$ \\
\hline Bale River & $2.26 \mathrm{mg} / \mathrm{kg}$ & $15.13 \mathrm{mg} / \mathrm{kg}$ \\
\hline Reuleng River & $2.16 \mathrm{mg} / \mathrm{kg}$ & $16.52 \mathrm{mg} / \mathrm{kg}$ \\
\hline
\end{tabular}

eventually can lead to long-term population reduction and even extinction. The $\mathrm{Zn}$ content in the Reuleng River and Bale River is, however, still in normal capacity (Table 1), where the Zn threshold in food (according to Indonesian law) is $40.0 \mathrm{mg} / \mathrm{kg}$.

Such pollution, nevertheless, can affect the reproduction system, either directly or indirectly through the heavy metal accumulation in the reproduction organs. Reproduction regulation in mollusks is very complex and regulated by various factors and heavy metal pollution can affect any part of this system. The growth of industries and factories around the river has increased the river pollution potential.

\section{Histological Damage of Faunus ater Gonad}

The results reveal that the tissue damage on the reproduction system of Faunus ater, where in female gonad; (a) Oocyte average that has developed to gonadal maturity level is higher in the samples obtained from the Reuleng River than from the Bale River; (b) Oocyte average that has not developed to gonadal maturity level is higher in the samples obtained from the Releung River than from the Bale River; and (c) the average number of damaged oocytes is similar in the samples obtained from both locations, where the lobules are present in the damaged gonad due to the contaminants; thus, the development of oogonia to become oocyte cannot take place (Table 2). Meanwhile, the histological analysis in male gonad, it was found that the samples from the Bale River have higher quantity of spermatogenic cells that experience greater necrosis, than from the Reuleng River (Table 3).

The tissue damage in the reproduction system of Faunus ater results from the accumulation of

Table 2. Histological analysis of female Faunus ater gonads

\begin{tabular}{|c|c|c|c|c|c|c|c|c|c|c|c|c|c|}
\hline \multirow{2}{*}{ No } & \multirow{2}{*}{ Location } & \multicolumn{4}{|c|}{ Number of Mature Oocytes } & \multicolumn{4}{|c|}{ Number of Immature Oocytes } & \multicolumn{4}{|c|}{ Damaged Oocytes } \\
\hline & & Mean & SD & $\mathrm{t}$-Test & $\mathrm{p}$ & Mean & SD & Uji t & $\mathrm{p}$ & Mean & SD & $\mathrm{t}$-Test & $\mathrm{p}$ \\
\hline 1 & Bale River & 0.89 & 1.537 & \multirow{2}{*}{1.778} & \multirow{2}{*}{0.09} & 2.89 & 3.257 & \multirow{2}{*}{0.718} & \multirow{2}{*}{0.48} & 3.11 & 2.369 & \multirow{2}{*}{0.128} & \multirow{2}{*}{0.9} \\
\hline 2 & Reuleng River & 2.44 & 2.128 & & & 3.89 & 2.619 & & & 3.22 & 1.093 & & \\
\hline
\end{tabular}

Table 3. Histological analysis of male Faunus ater gonads

\begin{tabular}{|c|c|c|c|c|c|}
\hline \multirow{2}{*}{ No } & \multirow{2}{*}{ Location } & \multicolumn{3}{|c|}{ Necrosed Spermatogenic Cell } \\
\cline { 3 - 5 } & & Mean & SD & t-Test & P \\
\hline 1 & Bale River & 35.22 & 8.885 & \multirow{2}{*}{0.226} & 0.824 \\
\hline 2 & Reuleng River & 34.11 & 11.78 & & \\
\hline
\end{tabular}


pollutants that are found in the two rivers. The presence of $\mathrm{Pb}$ and $\mathrm{Zn}$ in the Bale River (Table 1) is one of other causes that lead to the lower gonadal maturity in the Bale River. This situation indicates that the pollution in the Bale River has taken an effect on the snail reproduction, where the nearby cement factory possibly gives the major contribution to this. The possibility of the heavy metal exposure on Faunus ater tissue increases, as the continuous accumulation of the heavy metals in the river body can form sedimentation. Therefore, it is more likely the bioaccumulation can occur within the gonadal tissue and affecting the oogenesis and spermatogenesis process in the organism. The $\mathrm{Pb}$ and $\mathrm{Zn}$ content has a correlation against the reproductive cells, thus affecting the gametogenesis (Jalius et al., 2016). It is in agreement with (Desouky, 2009), where the heavy metal exposed scallops experience a gamete development disorder, where even gametes are unable to degenerate.

Heavy metals can be exposed to snail tissue through oral pathway, where it is later carried by blood circulation with the chemical binding until it reached the target organ. Within a long period of time, the heavy metals are accumulated in the tissue and affect the physiological and biochemical activities. Darmono (1995) reported that stationary or slow mobility water plants and several mollusks (clams, snails, etc.) cannot regulate the metal-like other aquatic organisms.

The heavy metal exposure on Faunus ater in the Balee River and Reuleng River iaffects the gametogenic cell development disorder during the cellular proliferation. The abnormal development of gametogenic cells can be observed in Figure 1. In female gonad, the presence of lobules is observable in the sporadic spermatogenic sells. The heavy metal exposure induces the reduction of secondary spermatocyte and spermatozoa (Baršienè et al., 2008). This study finds that the lead exposure on female gonad can also cause seminiferous tubules and germ cells to experience damage and quantity reduction (Garu et al., 2011). This is in agreement with (Sukmaningsih, 2009), where it is reported that lead $(\mathrm{Pb})$ and cadmium $(\mathrm{Cd})$ from the cigarette smoke can reduce the quantity of pachytene spermatocyte and spermatid during spermatogenesis.

Contaminant chemicals, especially heavy metals such as $\mathrm{Pb}, \mathrm{Cd}, \mathrm{Cr}$ and $\mathrm{Hg}$, affect the development of reproductive cells in both the initial and final step. Moreover, in the cellular proliferation step of gametogonium, they hinder the mitotic division, especially during the metaphase that is very sensitive against the chemical change,

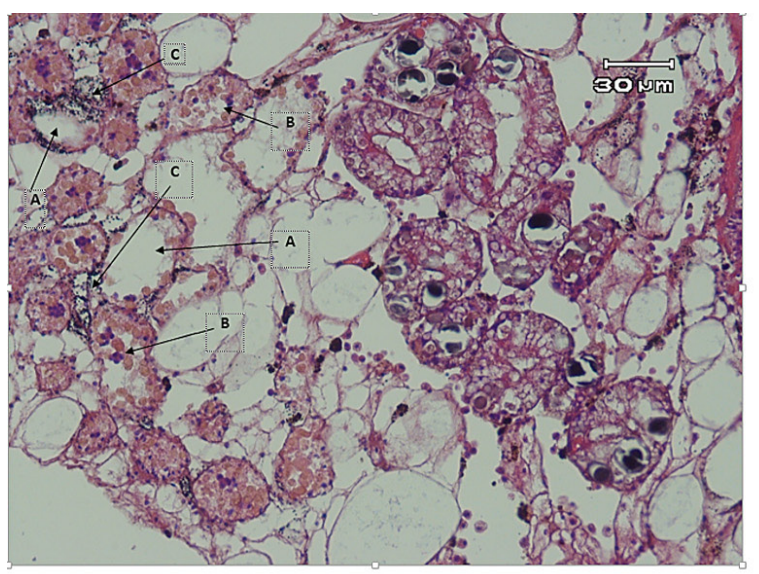

(a)

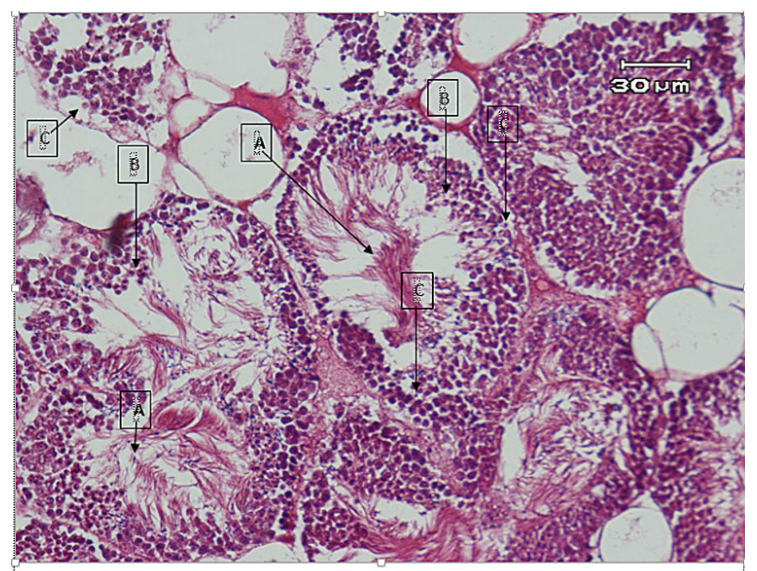

(b)

Figure 1. Histological image of (a) female and (b) male gonads of Faunus ater (Documentation, 2017)

Female Gonad:

A. Lobules with reduced oogonia, it is observable that the lobules are almost empty

B. Number of sporadic oogonia cells

C. Observable inflammatory cells surrounding the lobules

Male Gonad:

A. Spermatozoa

B. Spermatid

C. Necrosed spermatogenic 
temperature and environment. Furthermore, the heavy metal pollution affects the meiosis division; thus, the number of formed gametogenic cells is low. The heavy metal accumulation in the tissue causes unstable lysosome activities and its degradation, which further leads to the cell death (Jalius et al., 2016). Moore (1985) and Dumkova et al (2017) reported that the pollution of $\mathrm{Pb}, \mathrm{Cu}$ and $\mathrm{Cd}$ causes the instability of lysosome organelle membrane within the cell. In addition, it also gives an effect to oxidation, enzymatic activities and the equilibrium of $\mathrm{Ca}^{2+}$ ion within the cell. Last but not least, heavy metals are toxic and lead to bioaccumulation that can cause biotransformation within the cell, leading to cellular or tissue damage.

The heavy metal accumulation in Faunus ater from the two rivers occurs through food chain pathway. In the tissue, heavy metal may trigger the formation of Reactive Oxygen Species (ROS) compounds due the deactivated antioxidant enzymes such as Superoxide dismutase (SOD), Catalase (CAT) and Glutathione Peroxidase (GPOD). Heavy metals such as $\mathrm{Pb}$ enter the cytosol by potential inhibition of membrane physiological import. Heavy metals contaminate and bind small molecules (such as GSH) and carriers, namely chaperons and apoprotein (such as superoxide dis-mutase, cytochrome c oxidase). Chaperon and apoprotein may substitute natural ligand process from endogenic cations, thus hindering the homeostasis process of $\mathrm{Ca}$ and being accumulated in the metal rich particles or mineral. With the presence of reduction-oxidation in sulfur group, the formation of ROS may occur (Varotto et al., 2013).

The formed ROS inhibits the gene expression as well as antioxidant process of cellular organelles such as in mitochondria and lysosome. The inhibition may lead to cell death, either through necrosis or apoptosis (Varotto et al., 2013).

Other literature explained that the bioaccumulation of heavy metals occurs when the organism activates its self-defence mechanism by merging with the environment (Al-Halani, 2018), which include water, sedimentation, suspended solid, and predator organism. If the chemical merging exceeds the metabolism or chemical excretion, then bioaccumulation can occur (Osman and Kloas, 2010). Therefore, the tissue analysis can reveal the presence of contaminant which may not be detected otherwise (Osman and Kloas, 2010). Meanwhile, long term exposure of low-level pollutant on Fausnus ater may not exhibit clear or observable effect; however, the effect on reproductive system may again take place and affect the decrease of its offspring, where extinction can possibly happen in the future.

\section{CONCLUSION}

Faunus ater in the Reuleng River and Bale River is found with histological damage in its gonad, due to the presence of $\mathrm{Pb}$ and $\mathrm{Zn}$. The results obtained from this study suggest that the tissue damage in the reproductive system of Faunus ater has been observably occurred, where in female gonad: (a) Oocyte average that has developed to gonadal maturity level is higher in the samples obtained from the Reuleng River than from the Bale River; (b) Oocyte average that has not developed to gonadal maturity level is higher in the samples obtained from the Reuleng River than from the Bale River; And (c) the average number of damaged oocytes is similar in the samples obtained from both locations, where the lobules are present in damaged gonad due to the contaminants; thus, the development of oogonia to become oocyte cannot take place. Meanwhile, during the histological analysis in male gonad, it was found that the samples from the Bale River have higher quantity of spermatogenic cells that experience greater necrosis, than that from the Reuleng River. Even though the Bale River is located near the cement factory, where the wastewater of machine-washing process is discharged directly, the significant damage in Faunus ater gonad was not present, compared to the one from the Reuleng River. However, the spermatogenic development was observed to be better in Faunus ater gonad from the Reuleng River.

\section{REFERENCES}

1. Al-Halani, A.A., 2018. Effect of seasonal changes on physiological and Histological Characteristics of Nile tilapia (Oreochromis niloticus) Inhabited Two Different Freshwater Habitats. Int. J. Mod. Biol. Med. 9.

2. Anna Jakimska, Konieczka, P., Skóra, K., Namieśnik, J., 2011. Bioaccumulation of Metals in Tissues of Marine Animals, Part I: the Role and Impact of Heavy Metals on Organisms. Polish J. Environ. Stud. 20. 
3. Baršienè, J., Andreikènaitè, L., Garnaga, G., Rybakovas, A., 2008. Genotoxic and cytotoxic effects in the bivalve mollusks Macoma balthica and Mytilus edulis from the Baltic Sea. Ekologija 54, 4450. https://doi.org/10.2478/V10055-008-0009-x

4. Desouky, M.M.A., 2009. Pathological effects of environmental pollution on the ultrastructure of spermatogenic stages and the mature sperm of brachydontes variabilis (Krauss, 1848) (BivalviaMytilidae) 3, 2627-2636.

5. Duruibe, J.O., Ogwuegbu, M.O.C., Egwurugwu, J.N., others, 2007. Heavy metal pollution and human biotoxic effects. Int. J. Phys. Sci. 2, 112-118.

6. Garu, U., Sharma, R., Barber, I., 2011. Effect of lead toxicity on developing testis of mice. Int. J. Pharm. Sci. Res. 2, 2403.

7. Gatsogiannis, C., Hofnagel, O., Markl, J., Raunser, S., 2015. Structure of Mega-Hemocyanin Reveals Protein Origami in Snails. Structure 23, 93-103. https://doi.org/10.1016/j.str.2014.10.013

8. Govind, P., Madhuri, S., n.d. Heavy Metals Causing Toxicity in Animals and Fishes.

9. Jalius, J., Setiyanto, D.D., Sumantadinata, K., Riani, E., Ernawati, Y., 2016. Bioakumulasi Logam Berat Dan Pengaruhnya Terhadap Oogenesis Kerang Hijau (Perna viridis). J. Ris. Akuakultur 3, 43-52.

10. Müller, N., 2017. Characterization of dangerous pollutants in bio and waste ashes: Analysing content and leaching behaviour of several ashes for persistent organic pollutants and toxic heavy metals.

11. Osman, A.G.M., Kloas, W., 2010. Water Quality and Heavy Metal Monitoring in Water, Sediments, and Tissues of the African Catfish Clarias gariepinus (Burchell, 1822) from the River Nile, Egypt. J. Environ. Prot. (Irvine,. Calif). 01, 389-400. https:// doi.org/10.4236/jep.2010.14045

12. Sharaf, H.M., Shehata, A.M., 2015. Heavy metals and hydrocarbon concentrations in water, sediments and tissue of Cyclope neritea from two sites in Suez Canal, Egypt and histopathological effects. J. Environ. Heal. Sci. Eng. 13, 14. https://doi.org/10.1186/ s40201-015-0171-5

13. Sukmaningsih, A.A.S.A., 2009. Penurunan jumlah spermatosit pakiten dan spermatid tubulus seminiferus testis pada mencit (Mus musculus) yang dipaparkan asap rokok. J. Biol. Udayana 13.

14. Udayantha, H.M. V, Munasinghe, D.H.N., 2012. Investigation of the factors that influence on the distribution of mollusc, Faunus sp.(Mollusca: Gastropoda: Thiaridae) along the Lunuwila Ela, Galle. Ruhuna J. Sci. 4.

15. Varotto, L., Domeneghetti, S., Rosani, U., Manfrin, C., Cajaraville, M.P., Raccanelli, S., Pallavicini, A., Venier, P., 2013. DNA Damage and Transcriptional Changes in the Gills of Mytilus galloprovincialis Exposed to Nanomolar Doses of Combined Metal Salts (Cd, Cu, Hg). PLoS One 8, e54602. https:// doi.org/10.1371/journal.pone.0054602 